\title{
Uji Organoleptik dan Tigkat Keasaman Susu Kuda Liar dari Desa Penyaring Kecamatan Moyo Utara Kabupaten Sumbawa
}

\author{
Organoleptic Test And Acidity Level Of Wild Horse Milk In Penyaring Village, Moyo Utara District, \\ Sumbawa Regency
}

\author{
Sulfan Ardiansyah ${ }^{1 *}$, Candra Dwi Atma ${ }^{2}$, Alfiana Laili Dwi Agustin ${ }^{3}$, Kunti Tirtasari ${ }^{4}$ \\ ${ }^{1}$ Kelompok Ternak Kuda Liar Penyaring, ${ }^{2}$ Dosen Divisi Mikrobiologi dan Parasitologi, ${ }^{3}$ Dosen Divisi \\ Kesehatan Mayarakat Veteriner, ${ }^{4}$ Dosen Divisi Kesehatan Masyarakat Veteriner \\ Fakultas Kedokteran Hewan, Universitas Pendidikan Mandalika \\ *Corresponding author: ardiyansyah.sulfan@gmail.com
}

\begin{abstract}
Abstrak
Susu kuda liar Sumbawa merupakan salah satu susu murni hasil pemerahan kuda yang di pulau Sumbawa, Karna susu mengandung nilai gizi berkualitas tinggi sehingga perlu dilakukan pengawasan terhadap kualitasnya sebelum dikonsumsi oleh konsumen. Tujuan penelitian ini untuk mengetahui kualitas susu kuda liar secara organoleptik dan tingkat keasaman pada susu kuda liar di Desa Penyaring Kecamatan Moyo Utara. Sampel yang diambil sebanyak 5 dari 10 populasi, kemudian dilakukan uji Laboratorium Equine Clinical Skill Center Fakultas Kedokteran Hewan Universitas Pendidikan Mandalika untuk diperiksa. Pemeriksaan sampel susu dilakukan dengan metode uji warna, uji bau, uji rasa, uji keasaman, dan uji kekentalan. Hasil penelitian menunjukkan kualitas susu kuda liar sumbawa yang meliputi, warna, bau, rasa dan tingkat kekentalan menujukkan semuanya normal serta uji tingkat keasaman $(\mathrm{pH})$ menunjukkan $\mathrm{pH} 6$ yang berarti masih normal.
\end{abstract}

Kata kunci: Susu kuda liar sumbawa, uji organoleptik dan keasaman

\section{Abstract (In English)}

Sumbawa wild horse milk is one of the pure milk produced by horses bred on the island of Sumbawa, because milk contains high quality nutritional value. The purpose of this study was to determine the organoleptic quality of wild horse's milk and the acidity level of wild horse's milk in Penyaring Village, North Moyo District. Samples were taken from as many as 5 out of 10 populations, then the Equine Clinical Skill Center Laboratory of the Faculty of Veterinary Medicine, Mandalika Education University was tested for examination. Milk samples were examined using the color test, odor test, taste test, acidity test, and viscosity test. The results showed that the quality of Sumbawa wild horse milk which included color, smell, taste and viscosity showed that everything was normal and the acidity level test $(\mathrm{pH})$ showed $\mathrm{pH} 6$ which meant it was still normal.

Keywords: Sumbawa wild horse milk, organoleptic and acidity test

\section{Pendahuluan}

Susu kuda dimasyarakat dipakai sebagai bahan pangan untuk pemenuhan gizi, sehingga jaminan atas kualitas dan rasa susu kuda harus lebih diperhatikan, seperti halnya dalam proses pemerahan susu kuda sampai pengolahan susu yang pada akhirnya menjadi produk siap konsumsi. Bayak permasalahan yang terjadi pada peroses pengolahan, penyimpanan dan penggunaan susu karena kualitas susu dapat dengan mudah menurun. Penurunan kualitas susu diakibatkan karna keadan suhu ruangan 
yang tidak setabil dan adanya cemaran mikroba yang dipengaruhi oleh keadan saat pemerahan. (Suardan dan Swacita, 2009).

Susu kuda liar Sumbawa merupakan salah satu susu murni hasil perahan kuda yang diternak di pulau Sumbawa, Karna susu mengandung nilai gizi berkualitas tinggi. Hasil penilitian Laili et al., (2014) Selain itu, susu kuda liar juga memiliki keistimewan yaitu daya ketahannya terhadap kontaminasi mikroorganisasi pembusuk sehingga susu ini lebih tahan lama.

Komposisi susu berbagai mamalia bervariasi sangat luas karena faktor genetik, physiological dan faktor nutrisi serta lingkungan (Malancerne et al., 2002). Menurut Nurliyani (2003), komposisi kimia susu dapat dipngaruhi oleh berbagai macam faktor antara lain spesies, breed, individu, status nutrisi dan periode laktasi. Susu kuda dihasilkan oleh spesies ternak non ruminansia, sehingga berbeda dengan susu sapi atau kambing yang termasuk spesies ruminansia. Berbeda dengan sapi kuda tidak mempunyai rumen, sehingga kemampuan mencerna jenis pakan dan metabolismenya berbeda dan komposisi kimia, susu yang dihasilkan berbeda pula. Variasi komposisi kimia susu tersebut dapat menyebabkan variasi sifat-sifat fisiknya( Hakim et al., 2013).

Berdasarkan uraian diatas, maka data mengenai Uji Organoleptik dan tingkat keasaman susu kuda liar Sumbawa di Kecamatan Moyo Utara dapat digunakan sebagai acuan batas susu kuda dapat dikonsumsi atau tidak jika disimpan pada suhu ruangan.

\section{Materi dan Metode}

\section{Jenis dan Rancangan Penelitian}

Penelitiaan ini termasuk penelitian deskriptif dangan tipe studi survey. Epidimiologi deskriptif adalah suatu kegiatan pengumpulan data yang dilakukan pada suatu populasi wilayah tertentu pada waktu tertentu. Populasi pada penelitian ini adalah seluruh ternak kuda liar yang dipelihara dikandang kolektif desa penyaring kecamatan Moyo Utara. Sampel pada penelitian ini adalah individu ternak kuda liar yang diambil secara purposive sampling dikandang individu milik warga di desa penyaring. Jumlah sampel dalam penelitian ini adalah 5 sampel dari 10 populasi kuda.

\section{Waktu dan Tempat Penelitian}

Penelitian ini dilakukan pada bulan November 2020. Pengambilan sampel susu kuda liar diwilayah Moyo Utara, Kabupaten Sumbawa. Sampel akan di uji di Laboratorium CSC (Clinical skill center) Fakultas Kedokteran Hewan Universitas Pendidikan Mandalika.

\section{Metode Pemeriksaan \\ Pengambilan Sampel}

Sampel yang digunakan dalam penelitian ini yaitu 5 sampel susu kuda liar Sumbawa yang didapat dari peternak kuda liar dengan kriteria sedang pada punak laktasi yang masing-masing sampel berukuran $500 \mathrm{ml}$. Semua sempel disimpan dalam kotak dan disimpan dalam suhu kamar, karena selama penyimpanan pada suhu kamar susu kuda tidak mengalami kerusakan atau pembusukan (Hermawati dkk, 2004).

\section{Uji Warna}

Dalam tabung reaksi dimasukkan kurang lebih $5 \mathrm{ml}$ susu, kemudian dilihat dengan latar belakang putih. Diamati warna susu dan kemungkinan adanya kelainan pada warna susu. Warna susu normal (putih kekuningan) diberi skor 2 sedangkan warna susu yang menyimpang diberi skor 1 .

\section{Uji Bau}

Dalam tabung reaksi dimasukkan kurang lebih $5 \mathrm{ml}$ susu, kemudian dicium baunya. Bau susu normal : khas bau susu diberi skor 2 sedangkan bau yang menyimpang diberi skor 1 . 


\section{Uji Rasa}

Susu dituangkan sedikit ke gelas sloki kemudian dicicipi dan rasakan susu tersebut. Rasa susu yang menyimpang seperti rasa pahit (adanya kuman-kuman pembentuk pepton), rasa tengik (disebabkan oleh kuman asam mentega), rasa sabun (disebabkan oleh Bacillus lactic saponacei) rasa lobak (disebabkan oleh kuman E. coli), rasa anyir/amis (disebabkan oleh kuman tertentu pada mastitis) diberi skor 1. Sedangkan rasa susu normal : sedikit manis dan sedikit asin diberi skor 2 .

\section{Uji Kekentalan}

Susu sebanyak $5 \mathrm{ml}$ dimasukkan kedalam tabung reaksi kemudian dimiringkan secara perlahan-lahan. Diamati kecepatan susu mengalir dari dinding tabung. Susu normal akan membasahi dinding, tidak berlendir atau berbutir dan busa yg terbentuk akan segera hilang, diberi skor 2. Kekentalan susu menyimpang seperti mengental atau cair diberi skor 1.

\section{Uji Tingkat Keasaman (pH)}

Uji ini dilakukan untuk menentukan keasaman susu dengan menghitung log konsentrasi ion hidrogen (asam) dalam susu. Pada prinsipnya Susu segar mempunyai $\mathrm{pH}$ netral. Tingkat keasaman susu menurun karena fermentasi laktose menjadi asam laktat oleh mikroba (Suardana dan Swacita, 2009). Susu sebanyak $20 \mathrm{ml}$ dimasukkan ke dalam tabung reaksi kemudian dicelupkan kertas $\mathrm{pH}$ ke dalam tabung yang berisi susu. Hasilnya dibaca pada skala. pH optimum susu kuda liar.

\section{Analisis Data}

Data hasil penelitianakan disajikan secara deskriptif dengan menyajikan hasil Uji Organoleptik dan Tingkat Keasaman susu kuda liar di Desa Penyaring Kecamatan Moyo Utara Kabupaten Sumbawa.

\section{Hasil dan Pembahasan}

Hasil pemeriksaan susu kuda liar di laboratorium Equine CSC ( Clinical Skill Cernter ) Fakultas Kedokteran Hewan Universitas Pendidikan Mandalika dengan sampel susu kuda liar sebanyak 5 sampel dari 10 populasi di Desa Penyaring Kabupaten Sumbawa Seperti berikut :

Hasil uji warna pada sampel 1 hingga sampel 5 menunjukkan skor 2 yang artinya kelima warna sampel susu kuda liar dalam keadaan Normal dan tidak memgalami penyimpangan.

Tabel 1 Hasil uji warna susu kuda liar

\begin{tabular}{lllll}
\hline No & Sampel & Warna & Skor & Kualitas susu \\
\hline 1 & S.1 & Putih Kekuningan & 2 & Normal \\
2 & S.2 & Putih Kekuningan & 2 & Normal \\
3 & S.3 & Putih Kekuningan & 2 & Normal \\
4 & S.4 & Putih Kekuningan & 2 & Normal \\
5 & S.5 & Putih Kekuningan & 2 & Normal \\
\hline
\end{tabular}

Hasil uji Bau pada sampel 1 hingga sampel 5 menunjukkan skor 2 yang artinya kelima Bau sampel susu kuda liar dalam keadaan
Normal dan tidak menghasilkan Bau yang menyimpang.

Tabel 2 Hasil uji bau susu kuda liar

\begin{tabular}{lllll}
\hline No & Sampel & Bau & Skor & Kualitas susu \\
\hline 1 & S.1 & Khas bau susu kuda & 2 & Normal \\
2 & S.2 & Khas bau susu kuda & 2 & Normal \\
3 & S.3 & Khas bau susu kuda & 2 & Normal \\
4 & S.4 & Khas bau susu kuda & 2 & Normal \\
5 & S.5 & Khas bau susu kuda & 2 & Normal \\
\hline
\end{tabular}



Hasil uji Rasa pada sampel 1 hingga sampel 5 menunjukkan skor 2 yang artinya kelima Rasa sampel susu kuda liar dalam keadaan Normal dan tidak menunjukkan Rasa yang menyimpang.

Tabel 3 Hasil uji rasa susu kuda liar

\begin{tabular}{lllll}
\hline No & Sampel & Rasa & Skor & Kualitas susu \\
\hline 1 & S.1 & Sedikit Manis & 2 & Normal \\
2 & S.2 & Sedikit Manis & 2 & Normal \\
3 & S.3 & Sedikit Manis & 2 & Normal \\
4 & S.4 & Sedikit Manis & 2 & Normal \\
5 & S.5 & Sedikit Manis & 2 & Normal \\
\hline
\end{tabular}

Hasil uji Kekentalan pada sampel 1 hingga sampel 5 menunjukkan skor 2 yang artinya kelima kekentalan sampel susu kuda liar dalam keadaan Normal dan tidak menunjukkan kekentalan yang menyimpang.

Tabel 4 Hasil uji kekentalan susu kuda liar

\begin{tabular}{lllll}
\hline No & Sampel & Kekentalan & Skor & Kualitas susu \\
\hline 1 & S.1 & Khas susu kuda & 2 & Normal \\
2 & S.2 & Khas susu kuda & 2 & Normal \\
3 & S.3 & Khas susu kuda & 2 & Normal \\
4 & S.4 & Khas susu kuda & 2 & Normal \\
5 & S.5 & Khas susu kuda & 2 & Normal \\
\hline
\end{tabular}

Hasil uji tingkat keasaman pada sampel 1 menunjukkan tingkat keasaman susu pada pH (6 ), sampel 2 pada $\mathrm{pH}$ (6), sampel 3 pada $\mathrm{pH}$ (6), sampel 4 pada $\mathrm{pH}$ (6), dan sampel 5 pada PH (6). Berdasarkan penelitian (Eckles et al.,1973) Susu kuda segar dan normal memiliki $\mathrm{pH}$ berkisar 6 berarti menunjukkan sedikit asam.

Tabel 5 Hasil uji keasamam (pH) susu kuda liar

\begin{tabular}{llcl}
\hline No & Sampel & Keasaman (PH) & Kualitas susu \\
\hline 1 & S.1 & PH 6 & Normal \\
2 & S.2 & PH 6 & Normal \\
3 & S.3 & PH 6 & Normal \\
4 & S.4 & PH 6 & Normal \\
5 & S.5 & PH 6 & Normal \\
\hline
\end{tabular}

Berdasarkan hasil Uji organoleptik dan tingkat keasaman yang dilakukan dilaboratorium pada 5 sampel susu kuda liar menunjukkan: Uji warna (Normal) yaitu putih kekuningan, uji Bau (Normal) khas bau susu, uji kekentalan (Normal) susu membasahi dinding tidak berlendir atau berbutir dan busa yang berbentuk akan segera hilang, uji rasa (Normal) susu sedikit manis dan sedikit asam, dan uji tingkat keasaman (Normal) berkisar $\mathrm{pH} 6$ dengan sedikit asam.
Hasil penelitian ini menunjukan bahwa susu kuda liar sumbawa umur 3 sampe 5 tahun memiliki sistim fisiologis yang baik. Kuda betina yang dipelihara secara liar akan mencapai birahi pertama pada umur 12-15 bulan, kuda melahirkan anak pertama pada umur 2 sampe 3 tahun, dengan masa kebuntingan berkisar 315350 hari. Setelah melahirkan susu kuda sudah dapat dipera. Dalam satu laktasi selama 6 bulan, kuda dapat menghasilkan susu sebanyak 540 liter (Soeharsono, 2008). Rata-rata umur kuda dalam 
penelitian ini berkisar 3-5 tahun dan menjadi salah satu faktor normal dalam uji organoleptik.

Proses pemeliharaan kuda yang dilakukan oleh peternak di Desa Penyaring Kecamatan Moyo Utara mengutamakan prosedur sanitasi pemerahan dan pakan yang baik sehingga menghasilkan kualitas susu kuda yang baik. Sanitasi kandang adalah suatu kegiatan yang dilakukan oleh peternak untuk kebersihan kandang dan lingkungannya. Kegiatan ini penting karna dengan keadaan kandang serta lingkungan yang bersih, maka kesehatan kuda maupun peternak menjadi terjamin (Hasan, 2014). Sanitasi kandnag yang buruk dapat membuat ternak terinfeksi penyakit, salah datu penyakit yang dappat menginfeksi ternak adalah mastitis (Iskandar dkk., 2020)

Kesehatan dan pakan kuda liar di Desa Penyaring Kecamatan Moyo Utara sangan diperhatikan khususnya ambing kuda karna akan berpengaruh pada susu yang dihasilkan, maka dari itu sebelum diperah ambing kuda harus dibersihkan terlebih dahulu dengan air hangat. Berdasarkan spesiesnya kuda merupakan mamalia namun kebutuhan gizi yang diperlukan kuda tidaklah sama dengan kebutuhan hewan ternak mamalia lainnya seperti sapi atau kambing. (Rahmawati, 2011). Pemberian pakan kuda liar di Desa Penyaring Kecamatan Moyo Utara yakni kuda di lar ( padang pengembala ) sehingga kuda tidak sulit menemukan pakan yang baik (Hammer 1993).

\section{Kesimpulan}

Kesimpulan yang dapat ditarik dari penelitian ini adalah dari 5 sampel terhadap kualitas susu kuda liar sumbawa yang meliputi, warna bau, rasa dan tingkat kekentalan menujukkan semuanya normal serta uji tingkat keasaman $(\mathrm{pH})$ menunjukkan pH 6 yang berarti masih sesuai SNI.

\section{Ucapan Terima Kasih}

Terima kasih Kepada semua pihak yang telah membantu kelancaran pembuatan artikel ilmiah ini.

\section{Daftar Pustaka}

Badan Kordinasi Penanaman Modal Satu Pintu Kabupaten Sumbawa (2012) http://ptsp.bkpm.go.id/ptsp2012/inde x.php?r=profilptsp/view\&id_ptsp=1 5

Bennet, D. dan Hoffman, R.S. (1999). Equus caballus Linnaeus. American Society of Mammalogist.

Ditjennak Kementrian RI. 2015. Populasi Kuda Menurut Propinsi http://www.pertanian.go.id/ap_pages /mod/datanak Diakses tanggal 20 April 2016

Hakim, N. S. I.K., I. P. Suada,dan Sampurna. 2013. Ketahanan Susu Kuda Sumbawa pada Penyimpanan Suhu Ruang Ditinjau Dari Total Asam, Uji Didih dan Warna. Indonesia Medicus Veterinus Vol. 2(4): 369 - 374.

Hammer, D. 1993. Care of the Stable Horse. B. T. Batsford Ltd. London.

Hasan, A. M. A. 2014. Identifikasi Penyebab dan Nilai Ekonomi Kerugian Mortalitas Ternak Kuda Di Kecamatan Campalagian Kabupaten Polewali Mandar. [skripsi]. Makasar: Universitas Hasanuddin.

Hermawati, D., M. Sudarwanto,S. T. Soekarto, F. R.Zakaria, S. Sudardjat, dan Tjatur F. S. Rasa.2004.Aktivitas Antimikroba pada Susu Kuda Sumbawa.Jurnal Teknologi dan Industri Pangan Vol.15 (1): 47 - 53.

Iskandar, R., K. Tirtasari., N. S. I . Ningtyas., A. L. D. Agustin. 2020.

Residu Antibiotik Pada Susu 
Kambing Peranakan Etawa (Pe) Yang Menderitamastitis Subklinis Di Desa Aikmual Kabupaten Lombok Tengah. Jurnal Vitek Bidang Kedokteran Hewan. Vol. $10: 58-61$

Rahmawati, Putri. 2011. Pengaruh Pakan Terhadap Performa Reproduksi Kuda Betina di Kuda "Tombo Ati Stable" Salatiga. Universitas Gadjah Mada.

Laili, F. N., E. Setiowati dan S.Iravati.2014 Susu Kuda Sumbawa Khas Indonesia Bahan Antibakteri Jerawat (Staphylococcus epidermis). Trad Med. J. Vol.19(2): 74 - 79.

Malancarne, M. F., A. Martuzzi, Summer dan P. Mariani. 2002. Protein dan Fat Composition of Mare's Milk: Some Nutrisional Remarks with Reference 37 to Human and Cow's milk. Review.Internasional Daily Jurnal Vol. 12 (3): 210-230

Ressang, A.A. dan A.M. Nasution. 1992. Pedoman Mata Pelajaran Ilmu Kesehatan Susu. Fakultas Kedokteran Hewan, Institut Pertanian Bogor.

Nurliyani.2003. Komposisi kimia dan protein susu kuda pada sds-page (sodium dodecyl sulfate polyacrylamide gel electrophoresis). Buletin Peternakan Vol. 27 (2): 86 - 93.

Nasution (1992), Metode penelitian Naturalis Kualitif, Penerbit Tarsito, Bandung.

Saragih. C. I. I.,K. Suada, danI. P. Sampurna.2013. Ketahanan Susu Kuda Sumbawa Ditinjau dari Waktu Reduktase, Angka Katalase,
Berat Jenis, dan Uji Kekentalan. Indonesia Medicus Veterinus Vol. 2(5): $553-561$.

Schmidt GH, Van Vleck LD, Hutjens MP. 1992. Principles of Dairy Science. 2th Ed. New Jersey (US): Prentice Hall.

Soeharsono. 2008. Laktasi. Widya Padjadjaran. Bandung.

Suardana, IW., dan I.B.N Swacita, 2009. Higiene Makanan. Kajian Teori dan Prinsip Dasar. Udayana Universitas Press. ISBN 978-9798286-76-6 